\title{
PENGARUH LIKUIDITAS, LEVERAGE, PROFITABILITAS, DAN UKURAN PERUSAHAAN TERHADAP FINANCIAL DISTRESS DI SEKTOR TRADE, SERVICE, AND INVESMENT
}

\author{
Hasivatus Sariroh \\ Universitas Negeri Surabaya \\ hasivatussariroh@mhs.unesa.ac.id
}

\begin{abstract}
This study is a quantitative study that aims to determine the effect of the current ratio, debt to asset ratio, return on assets, and firm size on financial distress. Logistic regression method was used to test all relationships between independent variables and dependent variables with nominal/ordinal data scales. The dependent variable in this study is financial distress. The independent variables in this study are liquidity, leverage, profitability and firm size. This study uses secondary data from annual reports of trading, service, and investment companies listed on the Indonesia Stock Exchange from 2016 to 2018. The population used is companies in the trade, services, and investment sectors listed on the Indonesia Stock Exchange (IDX). from 2016 to 2018 with a total of 162 companies selected using purposive sampling technique. The results of hypothesis testing indicate that the current ratio, debt to asset ratio, return on assets, and firm size have no effect on the company's financial distress. From research conducted by researchers, for management to be used as a basis to take corrective actions if there are indications that the company experiencing financial distress. For investors, to be used as a basis in making the right decision to invest in a company.
\end{abstract}

Keywords: current ratio; company size; debt to asset ratio; financial distress; return on asset.

\section{PENDAHULUAN}

Dewasa ini, perusahaan menghadapi persaingan yang semakin ketat dan berimbas pada pengeluaran biaya yang semakin tinggi, yang pada akhirnya akan memengaruhi kinerja perusahaan bahkan mengalami kerugian. Apabila perusahaan tidak mampu memenangkan persaingan, maka perusahaan tersebut dapat menurun angka penghasilannya bahkan mengalami financial distress. Perusahaan yang mengalami masalah keuangan, biasanya mereka akan mencoba mengatasi masalahnya dengan berhutang, melakukan kombinasi bisnis, atau bahkan menutup usahanya (Andre \& Taqwa, 2014). Adanya potensi kesulitan keuangan yang dimiliki oleh perusahaan menyebabkan kekhawatiran dari berbagai pihak baik sektor internal seperti manajer dan karyawan, maupun pihak eksternal perusahaan seperti investor dan kreditur. Pihak investor akan kehilangan saham yang ditanamkan di perusahaan tersebut dan pihak kreditur akan mengalami kerugian karena telah meminjamkan modal yang tidak bisa dilunasi oleh perusahaan (Lindawati, 2014).

Seorang investor harus jeli saat menginvestasikan dananya. Hal ini perlu untuk memastikan dana yang diinvestasikan aman. Sehingga, sebelum memutuskan untuk berinvestasi, investor akan memerhatikan kondisi kesehatan keuangan suatu perusahaan. Kondisi keuangan perusahaan yang kurang baik akan mendatangkan kesulitan bagi perusahaan di mana hal ini berpengaruh terhadap kegagalan bisnis perusahaan yang berujung pada kegagalan finansial atau biasa dikenal dengan istilah financial distress (Ningsih, 2012). Financial distress terjadi sebelum perusahaan menghadapi kegagalan ataupun kebangrutan. Kondisi financial distress merupakan kondisi keuangan perusahaan dalam keadaan tidak sehat atau krisis (Carolina \& Pratama, 2017). Perusahaan yang mengalami financial distress memerlukan suatu prediksi yang akan membantu pihak manajemen dalam pengambilan keputusan untuk memerbaiki kondisi keuangan perusahaan sebelum terjadi kebangkrutan. Bagi pihak eksternal, prediksi financial distress diperlukan sebelum melakukan investasi atau memberikan pinjaman (Ayu et al., 2017).

Kebangkrutan suatu perusahaan dapat dilihat dan diukur melalui laporan keuangan di mana hal ini akan memberikan sumber informasi yang sangat penting sehingga data keuangan harus dikonversi 
Hasivatus Sariroh. Pengaruh Likuiditas, Leverage, Profitabilitas, dan Ukuran Perusahaan terhadap Financial Distress di Sektor Trade, Service, and Invesment

menjadi informasi yang berguna dalam pengambilan keputusan ekonomis (Mas'ud \& Srengga, 2015). Laporan keuangan yang diterbitkan oleh perusahaan merupakan ringkasan dari transaksi dan aktivitas perusahaan dalam satu periode, yang menjadi sumber informasi tentang posisi keuangan perusahaan, kinerja, serta perubahan posisi keuangan. Analisis laporan keuangan digunakan untuk memproyeksikan aspek keuangan perusahaan di masa yang akan datang untuk menghindari perusahaan dari kebangkrutan, serta dapat menjadi penentu kebijakan dan pertimbangan bagi manajer, investor, dan pemilik perusahaan (Patunrui \& Yati, 2018).

Penelitian terdahulu mengenai financial distress menggunakan beragam metode dalam mengkategorikan suatu perusahaan mengalami financial distress (Carolina \& Pratama, 2017). Eloumi and Gueyie, (2001) mengelompokkan perusahaan dalam kondisi financial distress apabila perusahaan memliki Earning Per Share (EPS) bersifat negatif. Wardhani (2007) menggunakan Interest Coverage Ratio (ICR). Almilia \& Kristijadi (2003) menggunakan dua jenis penilaian financial distress yaitu kondisi pertama perusahaan yang merugi berturut-turut sampai dua tahun, sedangkan kondisi yang kedua adalah perusahaan merugi dan nilai buku ekuitas negatif dua tahun berturutan.

Menurut Eloumi and Gueyie (2001), earning per share yang menunjukkan sisi negatif bahwa suatu perusahaan menuju kondisi kebangkrutan. Dibandingkan dengan rasio keuangan yang lain, pemegang saham memakai EPS untuk menilai prospek perusahaan di masa depan (Bodroastuti, 2009). Menurut para investor, earning per share adalah informasi dasar yang amat bermanfaat dan bisa mencerminkan nilai prospek perusahaan dikemudian hari (Tandelilin, 2010). Suatu perusahaan yang mempunyai nilai earning per share positif secara terus menerus pada setiap periodenya dapat dikatakan perusahaan tersebut memiliki pertumbuhan yang baik di masa depan. Sebaliknya, apabila nilai earning per share negatif dalam beberapa periode, ini menunjukkan prospek earning dan pertumbuhan perusahaannya tidak baik, sehingga hal tersebut kurang menarik bagi para investor. Dalam kondisi seperti itu, perusahaan akan sulit untuk mendapatkan dana sehingga dapat memicu terjadinya kebangkrutan (Whitaker, 1999).

Tabel 1.

NILAI EARNING PER SHARE PERSEKTOR PERIODE 2016-2018

\begin{tabular}{|c|c|c|c|}
\hline Sektor & $2016(\%)$ & $2017(\%)$ & $2018(\%)$ \\
\hline Agriculture & 8.43 & -13.3 & -3.21 \\
\hline Mining & 70.73 & 15.11 & 11.45 \\
\hline Basic Industry \& Chemicals & 31.96 & 28.06 & 24.01 \\
\hline Miscellaneous Industry & 29.64 & 0.77 & 0.96 \\
\hline Consumer Goods Industry & 12.56 & 23.11 & -10.21 \\
\hline Property, Real Estate and Building & & & \\
\hline Construction & 5.47 & -4.31 & -9.64 \\
\hline $\begin{array}{l}\text { Infrastructure, Utilities, and } \\
\text { Trasportation }\end{array}$ & 7.57 & 12.14 & -10.09 \\
\hline Finance & 18.17 & 40.52 & 3.05 \\
\hline Trade, Services, and Investment & 1.31 & 7.08 & -14.94 \\
\hline
\end{tabular}

Sumber: IDX Statistik (2018, data diolah)

Berdasarkan Tabel 1, nilai earning per share yang dimiliki oleh setiap sektor yang terdapat di BEI periode 2016-2018. Nilai earning per share tertinggi pada tahun 2016 adalah sektor Mining sebesar $70.73 \%$ dan yang terendah sektor Trade, Services, and Investment sebesar 1.31\%. Pada 2017, nilai earning per share tertinggi adalah sektor Finance sebesar $40.52 \%$ dan yang terendah sektor Property, Real Estate, and Building Construction sebesar $-4.31 \%$. Pada 2018, nilai earning per share tertinggi adalah sektor Basic Industry \& Chemicals sebesar $24.01 \%$ dan terendah sektor Trade, Services, and Investment sebesar - $14.94 \%$. 
Dari earning per share (EPS) pada Bursa Efek Indonesia (BEI) pada 2016-2018, maka objek penelitian terpilih pada sektor trade, service and invesment sebab dilihat dari grafik tersebut menjelaskan sektor trade, service and invesment meningkat secara fluktuatif. Pada 2016, pertumbuhan earning per share yang dimiliki bidang trade, service, and invesment sebesar $1.31 \%$, pada 2017 di angka 7.08\% sedangkan 2018 di angka 14.94\%. Perubahan tersebut menunjukkan sektor trade, service, and invesment mengalami situasi buruk di mana pertumbuhannya dalam angka terendah yaitu sebesar -14.94\% pada 2018 (IDX Statistik, 2018).

Deteksi financial distress pada suatu perusahaan dapat dilakukan dengan analisis rasio keuangan. Secara umum, rasio-rasio seperti profitabilitas, likuiditas, leverage, dan ukuran perusahaan merupakan indikator yang paling signifikan dan sering digunakan dalam memprediksi financial distress suatu perusahaan (Andre \& Taqwa, 2014).

Rasio likuiditas merupakan rasio yang mengukur kemampuan perusahaan dalam melunasi hutang yang telah jatuh tempo baik hutang dari pihak eksternal maupun internal perusahaan. Pada penelitian ini rasio likuiditas diukur dengan proksi current ratio $(C R)$. Current ratio adalah rasio yang menunjukkan kemampuan perusahaan dalam melunasi kewajiban jangka pendek yang akan jatuh tempo pada saat penagihan secara menyeluruh (Nukmaningtyas \& Worokinasih, 2018). Menurut Nurhidayah \& Rizqiyah (2017), Ardian et al. (2016), dan Ripais (2014), current ratio berpengaruh signifikan positif terhadap financial distress. Sedangkan Lindawati (2014), Kholidah et al. (2016), dan Adi et al. (2018) menjelaskan bahwa CR memiliki pengaruh negatif terhadap financial distress. Namun berbeda dengan penelitian Dewi \& Dana (2017) bahwa current ratio (CR) tidak berpengaruh terhadap financial distress.

Rasio leverage adalah rasio yang digunakan untuk mengukur sejauh mana utang yang digunakan dalam membiayai aset perusahaan, artinya berapa besar utang yang ditanggung perusahaan dibandingkan dengan asetnya, dapat dikatakan rasio ini digunakan untuk mengukur kemampuan perusahaan untuk membayar seluruh kewajiban baik jangka pendek maupun jangka panjang apabila perusahaan dilikuidasi (Nukmaningtyas \& Worokinasih, 2018). Rasio leverage yang digunakan adalah debt to asset ratio atau yang disebut debt ratio yaitu hutang lancar dibagi total asset. Debt to asset ratio (DAR) merupakan rasio yang digunakan untuk mengukur aset yang digunakan untuk menjamin keseluruhan kewajiban yang dimiliki oleh perusahaan (Yustika, 2015). Penjelasan ini sejalan dengan penelitian Kholidah et al. (2016) dan Suprobo et al. (2017) debt to asset ratio memiliki pengaruh signifikan yang positif terhadap financial distress. Namun, Kazemian et al. (2017) menyatakan bahwa debt to asset ratio berpengaruh signifikan negatif terhadap financial distress. Carolina \& Pratama (2017) menunjukkan bahwa debt to asset ratio tidak berpengaruh terhadap financial distress.

Rasio profitabilitas dapat digunakan untuk memprediksi financial distress (Kasmir, 2008:196). Rasio profitabilitas merupakan rasio yang digunakan untuk menilai kemampuan perusahaan dalam mencari keuntungan, tingkat profitabilitas yang selaras akan menjadi tolak ukur bagaimana suatu perusahaan mampu bertahan dalam bisnisnya dengan memperoleh laba (return) yang mencukupi apabila dibandingkan dengan risikonya, semakin tinggi laba yang diperoleh maka semakin kecil kemungkinan perusahaan akan mengalami financial distress (Nukmaningtyas \& Worokinasih, 2018). Dalam penelitian ini, rasio profitabilitas diukur dengan return on asset (ROA). Harahap (2011:305) menjelaskan ROA merupakan rasio yang menggambarkan perputaran aset perusahaan yang diukur dari volume perusahaan. ROA menunjukkan efisiensi dan efektivitas penggunaan aset perusahaan di mana rasio ini mengukur kemampuan suatu perusahaan dalam menghasilkan laba berdasarkan aset yang digunakan. Nilai ROA yang tinggi mencerminkan efisiensi pengelolaan aset perusahaan yang artinya perusahaan mampu menggunakan asetnya untuk menghasilkan laba. Penjelasan mengenai variabel ROA sejalan dengan penelitian Muflihah (2017) dan Mas'ud \& Srengga (2015) yang menunjukkan bahwa return on asset (ROA) berpengaruh signifikan positif terhadap financial distress. Sedangkan penelitian oleh Dewi \& Dana (2017) dan Nukmaningtyas \& Worokinasih (2018) menunjukkan bahwa ROA berpengaruh negatif dan signifikan terhadap financial distress. Namun, 
Hasivatus Sariroh. Pengaruh Likuiditas, Leverage, Profitabilitas, dan Ukuran Perusahaan terhadap Financial Distress di Sektor Trade, Service, and Invesment

penelitian Hidayat \& Meiranto (2014) menunjukkan bahwa ROA tidak berpengaruh signifikan terhadap financial distress.

Ukuran perusahaan juga dapat digunakan untuk melihat apakah suatu perusahaan sedang mengalami financial distress. Ukuran perusahaan mendeskripsikan seberapa besar jumlah aset yang dimiliki perusahaan tersebut. Hal ini dapat dilihat dari total aset perusahaan. Jika jumlah aset yang dimiliki suatu perusahaan bernilai besar, perusahaan tersebut akan lebih stabil keadaanya bahkan lebih kuat dalam menghadapi ancaman financial distress. Penjelasan ini sejalan dengan penelitian Nanayakkara \& Azeez (2015) yang menunjukkan bahwa ukuran perusahaan berpengaruh positif dan signifikan terhadap financial distress. Sedangkan Waqas \& Md-Rus (2018) menyatakan bahwa ukuran perusahaan berpengaruh signifikan negatif terhadap financial distress. Namun, penelitian Rahayu \& Sopian (2017) menunjukkan bahwa ukuran perusahaan tidak berpengaruh terhadap financial distress.

Penelitian ini dilakukan untuk mengetahui apakah rasio keuangan yaitu rasio likuiditas, leverage, protfitabilitas dan ukuran perusahan berpengaruh terhadap kondisi financial distress pada perusahaan sektor trade, service, and investment periode 2016-2018.

\section{KAJIAN PUSTAKA DAN PENGEMBANGAN HIPOTESIS}

\section{Signalling Theory}

Teori sinyal (Signaling Theory) dikembangkan oleh Ross pada 1977 yang menjelaskan mengenai dorongan perusahaan untuk memberikan informasi sinyal positif (good news) maupun sinyal negatif (bad news) kepada pihak eksternal mengenai kondisi perusahaan. Sinyal tersebut dapat berupa informasi yang terkandung dalam laporan keuangan. Dengan adanya informasi tersebut, diharapkan dapat membantu investor dalam mengambil keputusan melakukan investasi. Teori sinyal yang memberikan informasi keuangan dapat mengurangi terjadinya asimetris informasi antara pihak manajemen dan pihak investor. Terjadinya asimetris informasi disebabkan karena pihak manajemen mempunyai informasi lebih banyak mengenai prospek perusahaan, sedangkan pihak investor tidak mempunyai informasi mengenai prospek suatu perusahaan (Santoso et al., 2017).

Signal adalah suatu keputusan dari pengatur perusahaan dalam mengarahkan investor untuk prospek kondisi suatu perusahaan (Brigham and Houston, 2001;36). Suatu sinyal yang berpengaruh pada keputusan investor atau kreditur merupakan informasi yang dikeluarkan oleh perusahaan. Sinyal tersebut berupa laporan keuangan perusahaan, harga saham atau informasi lain yang menggambarkan kondisi suatu perusahaan. Laporan keuangan perusahaan digunakan untuk mengetahui kondisi perusahan berada dalam kondisi stabil atau mengalami financial distress. Kondisi perusahaan yang stabil ditunjukan dengan pendapatan laba dalam waktu yang relatif panjang. Kinerja perusahaan dikatakan baik apabila laba yang dilaporkan perusahaan meningkat karena bisa menghasilkan keuntungan hal ini berhubungan dengan pembagian deviden kepada pemegang saham (Sari \& Putri, 2016). Dasar pemikiran teori persignalan ialah terdapat perbedaan informasi antara yang didapatkan perusahaan dengan stakeholder lain. Informasi yang dimiliki manajemen perusahaan lebih berkualitas dan terpercaya dibandingkan pemililik perusahaan lainnya (Wibowo, 2014). Perusahaan dikatakan mengalami kondisi financial distress adalah perusahaan yang berada dalam kondisi keuangan yang kurang sehat, sehingga hal ini akan menjadi informasi dianggap kurang bagus oleh pihak luar begitu juga sebaliknya, perusahaan yang berada dalam kondisi financial distress tidak ingin memberikan infomasi keuangannya kepada pihak luar seperti investor dan kreditur. Namun bagi investor dan kreditur, informasi tersebut sangat berguna agar mereka tidak mengambil keputusan yang salah yang dapat merugikan perusahaan (Sari \& Putri, 2016).

\section{Financial Distress}

Tahap di mana suatu perusahaan dengan kondisi keuangan menurun dan merupakan tahap sebelum terjadinya kebangkrutan merupakan pengertian dari financial distress (Platt \& Platt, 2002). Menurut Andre \& Taqwa (2014), financial distress terjadi karena perusahaan tidak mampu dalam mengelola 
dan menjaga kestabilan kinerja keuangan perusahaannya yang bermula dari kegagalan dalam mempromosikan produk yang dibuatnya yang menyebabkan turunnya penjualan sehingga dengan pendapatan yang menurun dari sedikitnya penjualan memungkinkan perusahaan mengalami kerugian operasional dan kerugian bersih untuk tahun yang berjalan, kerugian yang terjadi akan mengakibatkan defisiensi modal dikarenakan penurunan nilai saldo laba yang terpakai untuk melakukan pembayaran dividen sehingga total ekuitas secara keseluruhan pun akan mengalami defisiensi. Apabila hal ini berulang secara terus-menerus, jumlah kewajiban perusahaan dapat lebih besar dibanding total aset perusahaan.

Fahmi (2011) mengkategorikan persoalan financial distress menjadi empat di antaranya ialah sebagai berikut. (1) Kategori A atau sangat tinggi, keadaan ini memungkinkan perusahaan dinyatakan berada di posisi bangkrut atau pailit, selain itu memungkinkan pula pihak perusahaan melaporkan ke pihak terkait seperti pengadilan bahwa perusahaan telah berada dalam posisi bankruptcy (pailit) dan menyerahkan berbagai urusan untuk ditangani oleh pihak luar perusahaan. (2) Kategori B atau tinggi, adalah kondisi di mana perusahaan harus mencari solusi realistis untuk melindungi seluruh aset yang dimiliki, seperti sumber aset yang ingin dijual dan dipertahankan, termasuk memikirkan berbagai dampak apabila dilaksanakan keputusan merger (penggabungan) dan akuisisi (pengambilan). Salah satu dampak jika perusahaan berada pada posisi ini yaitu perusahaan mulai melakukan PHK (Pemutusan Hubungan Kerja) dan pensiun dini pada beberapa karyawannya yang dianggap tidak layak (infeasible) lagi untuk dipertahankan. (3) Kategori $\mathrm{C}$ atau sedang, yaitu perusahaan bisa menyelamatkan diri. Perusahaan dapat mengadakan tindakan tambahan dana untuk menyelamatkan perusahaannya. Salah satu keputusan yang dapat dilakukan adalah membeli lagi saham yang sudah terjual di pasaran. Keputusan ini mengandung beberapa arti bagi perusahaan yaitu perusahaan dapat mendapatkan saham yang sebelumnya dijual dipasaran, perusahaan akan memberikan sinyal positif ke pasaran yang di mana perusahaan tersebut mempunyai keadaan keuangan yang baik, nilai earning per share berpotensi meningkat. (4) Kategori D atau rendah, perusahaan mengalami fluktuasi financial temporer yang disebabkan oleh berbagai kondisi eksternal dan internal, termasuk pengambilan keputusan yang kurang tepat. Keadaan ini umumnya bersifat jangka pendek, sehingga bisa diatasi.

\section{Rasio Likuiditas}

Rasio likuiditas adalah rasio yang menggambarkan kemampuan perusahaan dalam melunasi kewajiban jangka pendek yang segera jatuh tempo. Rasio likuiditas diperlukan pada analisis kredit ataupun analisis resiko keuangan (Aisyah et al., 2017). Rasio likuiditas berfungsi untuk mengukur sejauh mana kemampuan perusahaan agar bisa melunasi hutang yang sudah jatuh tempo dari pihak eksternal perusahaan. Fungsi rasio ini disebut juga yaitu kemampuan perusahaan dalam mengetahui, membiayai dan memenuhi hutang yang tertagih (Kasmir, 2008:129). Perusahaan yang terhindar dari ancaman financial distress adalah perusahaan yang mempunyai kinerja yang bagus (Rahayu \& Sopian, 2017). Rasio likuiditas pada penelitian ini terukur dari current ratio. Current ratio mengukur kemampuan perusahaan memenuhi utang jangka pendeknya dengan menggunakan aktiva lancarnya, perusahaan yang mampu mendanai dan melunasi kewajiban jangka pendeknya dengan baik maka potensi perusahaan mengalami financial distress akan semakin kecil (Dewi \& Dana, 2017). Current ratio dihitung dengan menggunakan rasio antara aktiva lancar dengan hutang lancer seperti pada rumus (1).

current ratio $=($ aktiva lancar $) /($ utang lancar $) \times 100 \%$

\section{Rasio Leverage}

Leverage timbul karena perusahaan dibelanjai dengan dana yang menimbulkan beban tetap, yaitu berupa utang dengan beban tetapnya berupa bunga (Sudana, 2009:207). Leverage yang tinggi akan mengakibatkan perusahaan dalam kondisi financial distress apabila tidak diimbangi dengan ketersediaan dana atau aset yang memadai untuk melunasi hutang-hutangnya. Rasio leverage menunjukkan seberapa besar hutang yang dimiliki oleh perusahaan (jangka pendek dan jangka panjang). Keputusan pengambilan pendanaan dari pihak ketiga berada di tangan agent. Namun jika total hutang yang dimiliki perusahaan terlalu besar, maka perlu ditinjau lebih lanjut kinerja agent 
Hasivatus Sariroh. Pengaruh Likuiditas, Leverage, Profitabilitas, dan Ukuran Perusahaan terhadap Financial Distress di Sektor Trade, Service, and Invesment

dalam mengelola perusahaan. Karena jika total hutang perusahaan terlalu besar, financial distress perusahaan semakin rawan terjadi (Hidayat \& Meiranto, 2014). Penggunaan jumlah utang perusahaan tergantung pada keberhasilan perusahaan dalam menghasilkan pendapatan dan ketersediaan aset yang bisa digunakan sebagai jaminan atas utang tersebut (Gobenvy, 2014). Leverage diukur dengan menggunakan debt ratio dan debt equity ratio (Ayu et al., 2017).

Dalam penelitian ini, rasio leverage diukur menggunakan debt to asset ratio (debt ratio). Debt ratio merupakan rasio utang yang digunakan untuk mengukur perbandingan antara total utang dengan total aset, dengan kata lain, seberapa besar aset perusahaan dibiayai oleh utang atau seberapa besar utang perusahaan berpengaruh terhadap pengelolaan asset. Apabila rasionya tinggi, pendanaan hutang semakin banyak. Artinya, semakin sulit bagi perusahaan untuk memeroleh tambahan pinjaman karena dikhawatirkan perusahaan tidak mampu menutup utangnya dengan aset yang dimilikinya. Apabila rasionya rendah, semakin kecil perusahaan dibiayai dengan utang (Muflihah, 2017). Rumus debt ratio dapat dilihat di rumus (2).

debt to asset ratio $=($ total debt $) /($ total assets $) \times 100 \%$

\section{Rasio Profitabilitas}

Rasio profitabilitas merupakan rasio untuk menilai kemampuan suatu perusahaan dalam mencari keuntungan. Rasio ini juga memberikan ukuran tingkat efektivitas manajemen suatu perusahaan. Hal ini ditunjukkan oleh laba yang dihasilkan dari penjualan dan pendapatan investasi (Kasmir, 2008:196). Rasio profitabilitas menunjukkan kemampuan suatu perusahaan dalam mencetak laba. Jika agent berhasil dalam pengelolaan perusahaannya, berarti perusahaan tersebut mencetak laba yang tinggi. Dengan laba yang tinggi, investor akan tertarik untuk berinvestasi sehingga perusahaan jaug dari ancaman financial distress (Hidayat \& Meiranto, 2014). Penggunaan rasio profitabilitas dapat dilakukan dengan menggunakan perbandingan antara berbagai komponen yang ada di laporan keuangan, terutama laporan keuangan neraca dan laporan laba rugi. Pengukuran dapat dilakukan untuk beberapa periode operasi. Tujuannya adalah agar terlihat perkembangan perusahaan dalam rentang waktu tertentu, baik penurunan atau kenaikan, sekaligus mencari penyebab perubahan tersebut. Hasil pengukuran tersebut dapat dijadikan alat evaluasi kinerja manjemen selama ini, apakah mereka telah bekerja secara efektif atau tidak.

Pada penelitian ini, rasio profitabilitas diukur dengan proksi return on asset (ROA). Rasio ini mengukur kemampuan perusahaan dalam menghasilkan laba berdasarkan tingkat aset tertentu. Rasio yang tinggi menunjukkan efisiensi dan efektivitas pengelolaan aset perusahaan yang semakin baik dan dapat menghasilkan laba perusahaan yang semakin besar dan terhindar dari financial distress (Ayu et al., 2017). Rumus return on asset dilihat dapat di rumus (3).

$\mathrm{ROA}=($ laba bersih setelah pajak $) /($ total aset $) \times 100 \%$

\section{Ukuran Perusahaan}

Ukuran perusahaan menggambarkan seberapa besar perusahaan dan seberapa banyak total aset yang dimiliki oleh perusahaan (Ayu et al., 2017). Ukuran perusahaan menggambarkan seberapa besar total aset yang dimiliki perusahaan tersebut. Perusahaan yang memiliki total aset yang besar akan mudah melakukan diversifikasi dan cenderung lebih kecil mengalami kebangkrutan (Putri \& Merkusiwati, 2014). Perusahaan dengan total aset besar menunnjukkan bahwa perusahaan tersebut telah mencapai tahap kedewasaan karena dalam tahap ini arus kas perusahaan sudah positif dan dianggap memiliki prospek yang baik dalam jangka waktu yang relatif panjang (Rahayu \& Sopian, 2017). Pada penelitian ini, ukuran perusahaan diukur dari logaritma natural dari total aset yang dimiliki oleh perusahaan. Logaritma natural digunakan untuk memperhalus data total aset dan diharapkan mampu memperkecil perbedaan total aset yang terlalu besar antara perusahaan yang satu dengan yang lainnya. Rumus untuk menghitung ukuran perusahaan dapat dilihat di rumus (4). 


\section{Earning Per Share (EPS)}

Rasio laba per lembar saham (earning per share) atau disebut juga rasio nilai buku, merupakan rasio yang digunakan untuk mengukur sejauh mana manajemen dapat berhasil mencapai keuntungan bagi pemegang saham. Jika nilai rasio ini rendah maka dapat dikatakan bahwa manajemen belum dapat memberikan keuntungan untuk pemegang saham, namun jika rasio ini tinggi maka dapat dikatakan bahwa manajemen dapat meningkatkan kesejahteraan pemegang saham (Kasmir, 2010:115). Bagi para investor, informasi EPS merupakan informasi dianggap paling mendasar dan berguna, karena bisa menggambarkan prospek earning perusahaan di masa depan. Informasi EPS suatu perusahaan menunjukkan besarnya laba bersih perusahan yang siap dibagikan bagi semua pemegang saham perusahaan. Besarnya EPS suatu perusahaan bisa diketahui dari informasi laporan keuangan perusahaan. Meskipun beberapa perusahaan tidak mencantumkan besarnya EPS perusahaan bersangkutan dalam laporan keuangannya, tetapi besarnya EPS suatu perusahaan dapat dihitung berdasarkan informasi laporan neraca dan laporan rugi laba perusahaan (Tandelilin, 2010:374). Besarnya EPS suatu perusahaan bisa dihitung berdasarkan informasi laporan neraca dan laporan rugi laba perusahaan. Rumus untuk menghitung EPS suatu perusahaan dapat dilihat di rumus (5).

$$
\text { EPS }=(\text { laba bersih setelah bunga dan pajak }) /(\text { ju mlah saham beredar })
$$

\section{Hubungan antar Variabel}

Likuiditas perusahaan dalam penelitian ini diasumsikan menjadi alat prediksi kondisi financial distress suatu perusahaan dan diukur dengan current ratio, yaitu aset lancar dibagi dengan hutang lancar (CA/CL). Current ratio mengukur kemampuan suatu perusahaan memenuhi hutang jangka pendeknya dengan menggunakan aset lancarnya. Semakin besar rasio likuiditas, semakin kecil kemungkinan perusahaan mengalami kondisi financial distress dikarenakan perusahaan memiliki sejumlah aset yang likuid seperti kas atau uang yang digunakan untuk melunasi utangnya dan membiayai kegiatan operasionalnya baik pada periode transaksi sehingga perusahaan tidak mengalami kesulitan keuangan maupun terancam kelangsungan usahanya (Mas'ud \& Srengga, 2015).

Rasio likuiditas menunjukkan kemampuan perusahaan melunasi hutang jangka pendeknya. Keputusan hutang piutang berada di tangan agent. Hutang perusahaan saat ini merupakan keputusan masa lalu agent dalam melakukan pendanaan pihak ketiga. Jika suatu perusahaan memunyai hutang terlalu banyak, suatu saat perusahaan tersebut akan mempunyai kewajiban yang lebih tinggi untuk dilunasi. Apabila suatu perusahaan tidak dapat melunasi kewajibannya yang telah jatuh tempo, perusahaan tersebut akan semakin dekat dengan ancaman financial distress (Hidayat \& Meiranto, 2014).

Saleh \& Sudiyatno (2013) menganalisis rasio keuangan untuk memprediksi financial distress. Penelitian tersebut menghasilkan bahwa current ratio secara statistik tidak signifikan terhadap probabilitas kebangkrutan. Hal ini disebabkan karena current ratio merupakan pengukur likuiditas jangka pendek, sedangkan probabilitas kebangkrutan merupakan prediksi jangka panjang. Semakin besar aset lancar dalam suatu perusahaan, semakin baik kemampuan perusahaan dalam memenuhi kewajiban jangka pendeknya sehingga terhindar dari kemungkinan terjadinya probabilitas kebangkrutan.

\section{H1: Likuiditas berpengaruh terhadap kondisi financial distress perusahaan.}

Rasio leverage merupakan rasio yang digunakan untuk mengukur sejauh mana aset perusahaan dibiayai oleh hutang. Apabila pembiayaan suatu perusahaan lebih banyak menggunakan utang, hal ini beresiko akan terjadi kesulitan pembayaran di masa yang akan datang akibat utang lebih besar dari aset yang dimiliki. Jika keadaan ini tidak dapat diatasi dengan baik, potensi terjadinya financial distress pun semakin besar (Gobenvy, 2014). Penelitian Kholidah et al. (2016) menunjukkan bahwa Debt to assets ratio dapat memprediksi financial distress perusahaan dan memiliki pengaruh positif terhadap potensi financial distress perusahaan. Hal ini berarti semakin tinggi nilai debt to assets ratio, 
Hasivatus Sariroh. Pengaruh Likuiditas, Leverage, Profitabilitas, dan Ukuran Perusahaan terhadap Financial Distress di Sektor Trade, Service, and Invesment

maka semakin tinggi risiko perusahaan mengalami kondisi financial distress. Debt to assets ratio yang tinggi menunjukkan aset perusahaan banyak dibiayai oleh utang yang berdampak pada tingginya beban yang harus ditanggung.

\section{$\mathrm{H} 2$ : Leverage berpengaruh terhadap financial distress perusahaan.}

Return on total asset ratio (ROA) merupakan rasio yang menunjukkan hasil (return) atas jumlah aset yang digunakan dalam perusahaan, profitabilitas yang diukur dengan return on assets digunakan untuk mengukur tingkat pengahasilan bersih yang diperoleh dari total aset yang diperoleh perusahaan. Artinya, jika return on asset pada perusahaan meningkat, perusahaan akan terhindar dari financial distress. Namun sebaliknya, jika return on asset yang dimiliki perusahaan menurun, perusahaan akan mengalami financial distress (Carolina \& Pratama, 2017).

Aisyah et al. (2017) menganalisis rasio keuangan untuk memprediksi financial distress. Penelitian tersebut menunjukkan bahwa profitabilitas yang diukur dengan return on aset memiliki pengaruh terhadap financial distress. Rasio profitabilitas merupakan rasio yang mengukur kemampuan perusahaan dalam efisiensi dan efektivitas dari penggunaan total asetnya dalam menghasilkan laba. Dengan adanya keefektivitas dan efisiensi dari penggunaan aset perusahaan yang optimal, laba yang dihasilkan akan maksimal sehingga memiliki kecukupan dana untuk menutup biaya dan menjalankan usahanya. Dengan adanya kecukupan dana tersebut, kemungkinan perusahaan mengalami financial distress menjadi lebih kecil.

H3: Profitabilitas berpengaruh terhadap kondisi financial distress perusahaan.

Pertumbuhan perusahaan yang positif memberikan suatu tanda bahwa ukuran perusahaan tersebut semakin berkembang dan mengurangi kecenderungan ke arah kebangkrutan (Januarti, 2009). Untuk mempunyai pertumbuhan positif, perusahaan seharusnya mempunyai akses pasar dan akses operasional yang lebih baik dan lebih luas sehingga memiliki kemudahan untuk mendapatkan dana dalam jangka pendek dan keuntungan yang lebih besar dibandingkan dengan perusahaan kecil, sehingga perusahaan besar akan lebih mampu untuk menyelesaikan masalah keuangan yang dihadapi dan dapat mempertahankan kelangsungan usahanya. Ukuran perusahaan adalah skala yang menunjukkan besar kecilnya suatu perusahaan yang dapat diukur dengan berbagai cara, beberapa di antaranya adalah total aset, $\log$ size, dan nilai pasar saham. Namun, pada dasarnya ukuran perusahaan hanya terbagi dalam tiga kategori yaitu perusahaan besar (large firm), perusahaan menengah (medium-size), perusahaan kecil (small firm) (Gobenvy, 2014). Penelitian Putri (2014) menunjukkan ukuran perusahaan yang diukur dengan menggunakan total asset berpengaruh negatif pada financial distress karena semakin besar total aset yang dimiliki perusahaan, semakin meningkat kemampuan perusahaan dalam melunasi kewajibannya di masa depan sehingga perusahaan akan terhindar dari permasalahan keuangan.

H4: Ukuran perusahaan berpengaruh terhadap kondisi financial distress perusahaan.

\section{METODE PENELITIAN}

Penelitian ini termasuk ke dalam jenis penelitian konklusif. Sumber data didapat dari data sekunder yang diperoleh dari dokumentasi laporan keuangan tahunan perusahaan. Populasi yang digunakan adalah seluruh perusahaan sektor trade, services, and investment yang terdaftar di Bursa Efek Indonesia (BEI) pada tahun 2016-2018 dengan jumlah 162 perusahaan. Sektor trade, services, and investment dipilih dikarenakan nilai EPS dari sektor trade, services, and investment menunjukkan hasil yang selalu negatif atau menurun sejak tahun 2016-2018. Pengambilan sampel menggunakan teknik purposive sampling dengan kriteria penentuan sampel penelitian adalah perusahaan yang berturut-turut berada dalam sektor trade, service and, invesment selama periode 2016-2018 berjumlah 84 perusahaan, dan perusahaan sektor trade, service, and invesment yang tidak berturut-turut menerbitkan laporan keuangan selama periode 2016-2018 berjumlah 40 perusahaan. Sehingga, jumlah 
sampel yang digunakan adalah 38 perusahaan. Metode analisis data yang digunakan adalah regresi logistik yang meliputi menghitung variabel dependen, menilai model fit, koefisien determinasi, melakukan uji kesesuaian model persamaan regresi logistik, tingkat ketepatan klasifikasi yang mengukur keberhasilan persamaan regresi logistik, uji estimasi parameter dan interpretasinya, uji parsial, serta pengujian hipotesis.

\section{HASIL DAN PEMBAHASAN}

\section{Statistik Deskriptif}

Deskriptif statistik menjelaskan besarnya nilai rata-rata, deviasi standar, nilai minimum, dan nilai maksimum untuk variabel-variabel. Berdasarkan hasil perhitungan, diperoleh nilai rata-rata likuiditas sebesar 3,49009. Nilai minimum likuiditas sebesar 0,040 dan nilai maksimum likuiditas sebesar 118,220. Standar deviasi sebesar 11,954. Nilai rata-rata untuk variabel leverage yaitu sebesar 1,285. Nilai minimum leverage sebesar 0,009 dan nilai maksimum sebesar 19,970. Standar deviasi sebesar 3,481 . Nilai rata-rata dari variabel profitabilitas bernilai negatif sebesar 23,571 . Nilai minimum bernilai negatif sebesar 8719,920 dan nilai maksimum sebesar 5443,826. Standar deviasi sebesar 967,586 . Variabel ukuran perusahaan dengan nilai rata-rata sebesar 0,103 . Nilai minimum sebesar 0,042 dan nilai maksimum sebesar 0,128. Standar deviasi sebesar 0,020.

\section{Uji Hipotesis}

Analisis regresi logistik digunakan untuk mengetahui pengaruh variabel independen yaitu likuiditas, leverage, profitabilitas dan ukuran perusahaan terhadap financial distress. Hasil analisis regresi logistik dapat dilihat di Tabel 2.

Tabel 2.

\section{HASIL ANALISIS REGRESI LOGISTIK}

\begin{tabular}{|c|c|c|c|c|c|c|}
\hline Variabel & B & S.E. & Wald & Df & Sig. & $\operatorname{Exp}(B)$ \\
\hline X1 &,- 096 &, 076 & 1,563 & 1 &, 211 & ,909 \\
\hline $\mathrm{X} 2$ & $-1,655$ & 897 & 3,405 & 1 & 065 & ,191 \\
\hline X3 &, 000 & ,000 &, 024 & 1 & ,878 & 1,000 \\
\hline $\mathrm{X} 4$ & 1,904 & 9,911 & 037 & 1 & 848 & 6,713 \\
\hline Constant &, 529 & 1,269 & 174 & 1 & 677 & 1,697 \\
\hline
\end{tabular}

Sumber: Output SPSS (2021, data diolah)

Berdasarkan hasil analisis regresi logistik, pengaruh likuiditas, leverage, profitabilitas dan ukuran perusahaan terhadap financial distress dapat dilihat di persamaan matematis (6).

$$
\mathrm{Ln}(\mathrm{FD} / 1-\mathrm{FD})=0,529+0,096 \mathrm{CR}-1,655 \mathrm{DAR}+0,000 \mathrm{ROA}+1,904 \mathrm{UK}
$$

Hasil analisis koefisien determinasi dilihat pada Tabel 3. Perhitungan nilai cox dan snell $R$ square sebesar 0,102 atau $10,2 \%$ dan negelkerke $r$ square yang dihasilkan dari persamaan regresi mempunyai nilainya 0,138 atau $13,8 \%$. Ini menjelaskan kemampuan variabel independen memengaruhi variabel dependen sebesar $13,8 \%$, sedangkan sisanya dipengaruhi oleh variabel di luar penelitian sebesar $86,2 \%(100 \%-13,8 \%)$.

Ketepatan prediksi klasifikasi menunjukkan bahwa 69 unit observasi yang terkena financial distress diramalkan oleh model yaitu tepat 58 unit observasi sebagai mengalami financial distress dan 11 unit observasi sebagai tidak mengalami financial distress. Nilai kebenaran klasifikasi di angka 84,1\%. 45 unit dari observasi tidak terkena financial distress yang diramalkan tepat oleh model 30 unit observasi yang terkena financial distress tetapi model tak tepat meramalkan 15 unit observasi. Maka. nilai kebenaran klasifikasi sebesar 33,3\%. Nilai overall percentage sebesar $((58+15) / 114) \times 100 \%=64,0 \%$

Tabel 3.

HASIL ANALISIS KOEFISIEN DETERMINASI (MODEL SUMMARY) 
Hasivatus Sariroh. Pengaruh Likuiditas, Leverage, Profitabilitas, dan Ukuran Perusahaan terhadap Financial Distress di Sektor Trade, Service, and Invesment

\begin{tabular}{lccc}
\hline Step & $\mathbf{- 2} \mathbf{L o g}$ likelihood & Cox \& Snell R Square & Nagelkerke R Square \\
\hline 1 & $140,708^{\mathrm{a}}$ &, 102 &, 138 \\
\hline Sumber: & Output SPSS (2021, data diolah) &
\end{tabular}

\section{Pengaruh Current Ratio terhadap Financial Distress}

Hasil penelitian menunjukkan bahwa variabel likuiditas yang diproksikan dengan current ratio tidak berpengaruh negatif terhadap financial distress. Current ratio yang tinggi menggambarkan tingginya kemampuan perusahaan dalam melunansi utang lancar dengan menggunakan aset lancarnya (Muflihah, 2017). Semakin besar nilai current ratio maka semakin kecil potensi financial distress perusahaan dikarenakan perusahaan memiliki sejumlah aset lancar seperti kas atau uang yang digunakan untuk melunasi utangnya dan membiayai kegiatan operasionalnya baik pada periode transaksi ataupun periode yang akan datang sehingga perusahaan tidak mengalami kesulitan keuangan maupun terancam kelangsungan usahanya. Penelitian ini sejalan dengan Muflihah (2017) yang menyatakan bahwa current ratio tidak berpengaruh terhadap financial distress.

\section{Pengaruh Debt to Asset Ratio terhadap Financial Distress}

Berdasarkan hasil perhitungan yang telah dilakukan, variabel debt to asset ratio tidak berpengaruh negatif terhadap financial distress. Perusahaan yang memiliki debt to asset ratio yang tinggi menandakan perusahaan tersebut lebih banyak menggunakan utang dalam membiayai operasional perusahaan. Perusahaan yang memiliki banyak utang diprediksi akan mengalami financial distress. Namun hasil penelitian ini menunjukkan bahwa debt to asset ratio tidak terbukti memengaruhi atau tidak dapat digunakan untuk memprediksi kondisi financial distress sebuah perusahaan. Tidak adanya pengaruh ini kemungkinan disebabkan karena perusahaan memiliki aset yang cukup besar untuk menutupi hutang yang dimiliki oleh perusahaan sehingga perusahaan dapat menutupi kewajibankewajiban perusahaan yang telah jatuh tempo. Penelitian ini sejalan dengan Julius (2017) yang menyatakan bahwa laverage yang diproksikan dengan debt to asset ratio tidak berpengaruh terhadap financial distress.

\section{Pengaruh Return on Asset terhadap Financial Distress}

Berdasarkan hasil perhitungan analisis regresi logistik, variabel return on asset tidak berpengaruh terhadap financial distresss. Profitabilitas suatu perusahaan yang mengalami penurunan akan menyebabkan kondisi perusahaan mengalami financial distress. Sebaliknya, semakin tinggi profitabilitas, semakin kecil kemungkinan perusahaan akan mengalami financial distress. Hal itu dikarenakan kemampuan memperoleh laba perusahaan yang semakin tinggi akan memengaruhi kondisi keuangan yang baik sehingga tidak akan terjadi financial distress. Penelitian ini sejalan dengan Ardian et al. (2016) yang menyatakan bahwa return on asset tidak berpengaruh terhadap financial distress.

\section{Pengaruh Ukuran Perusahaan terhadap Financial Distress}

Berdasarkan hasil perhitungan yang telah dilakukan, variabel ukuran perusahaan tidak berpengaruh terhadap financial distress. Ukuran perusahaan menggambarkan seberapa besar total aset yang dimiliki oleh perusahaan. Suatu perusahaan yang memiliki total aset yang besar akan mudah melakukan diversifikasi dan cenderung lebih kecil mengalami kebangkrutan. Perusahaan yang memiliki ukuran perusahaan yang besar berarti memiliki aset yang besar di mana pembiayaan operasional perusahaan dari aktivanya bukan dari hutang berarti perusahaan tersebut memiliki struktur modal yang kuat. Perusahaan yang besar diukur dengan aset yang besar memiliki banyak konsekuensi di mana perusahaan tersebut mampu menciptakan laba lebih besar. Sehingga, pertumbuhan perusahaannya besar dan perusahaan tersebut mampu menyelesaikan hutang jangka pendek maupun hutang jangka panjang sehingga perusahaan akan terhindar dari kondisi financial distress.

\section{KESIMPULAN}

Berdasarkan hasil penelitian dapat ditarik kesimpulan sebagai berikut. (1) Current ratio tidak berpengaruh negatif terhadap financial distress. Hal ini berarti bahwa current ratio yang tinggi 
menggambarkan tingginya kemampuan perusahaan dalam melunansi utang lancer. Dengan menggunakan aset lancarnya, semakin kecil kemungkinan perusahaan mengalami kondisi financial distress. (2) Debt to asset ratio tidak berpengaruh negatif terhadap financial distress. Perusahaan dengan nilai debt to asset ratio yang tinggi memungkinkan perusahaan akan mengalami financial distress. Namun, perusahaan yang memiliki aset yang cukup besar dapat menutupi kewajibankewajiban perusahaan yang telah jatuh tempo. (3) Return on asset tidak berpengaruh terhadap financial distress. Kemampuan memeroleh laba perusahaan yang semakin tinggi akan memengaruhi kondisi keuangan yang baik sehingga semakin tinggi profitabilitas, semakin kecil kemungkinan perusahaan mengalami financial distress. (4) Ukuran perusahaan tidak berpengaruh terhadap financial distress. Ukuran perusahan menggambarkan seberapa besar total asset yang dimiliki perusahaan. Perusahaan dengan asset yang besar mampu menyelesaikan hutang jangka pendek maupun hutang jangka panjang sehingga perusahaan akan terhindar dari kondisi financial distress.

Model prediksi financial distress dapat digunakan sebagai pertimbangan dalam pengambilan keputusan manajemen untuk mengatur kinerja perusahaan khususnya yang berkaitan dengan kondisi keuangan perusahaan. Penelitian ini dapat membantu investor dalam melakukan investasi saham dengan melihat kondisi perusahaan melalui rasio keuangan, khususnya melalui rasio likuiditas, laverage, profitabilitas, dan arus kas. Penelitian selanjutnya dapat menggunakan objek penelitian selain perusahaan sektor trade, service, and invesment agar diperoleh model prediksi yang bervariasi dan menggunakan data lebih dari tiga tahun untuk penentuan perusahaan yang berpotensi mengalami financial distress agar kemampuan prediksi yang dihasilkan lebih baik. Penelitian selanjutnya juga dapat melibatkan variabel likuiditas, leverage, profitabilitas, dan ukuran perusahaan dengan menggunakan indikator lain selain earning per share dalam menguji financial distress, misalnya menggunakan interest coverage ratio.

\section{DAFTAR PUSTAKA}

Adi, A. N., Baridwan, Z., \& Mardiati, E. (2018). Profitability, Liquidity, Leverage and Corporate Governance Impact on Financial Statement Fraud and Financial Distress as Intervening Variable. Bulletin of Taras Shevchenko National University of Kyiv Economics, 5(200), 66-74.

Aisyah, N. N., Kristanti, F. T., \& Zultilisna, D. (2017). Pengaruh Rasio Likuiditas, Rasio Aktivitas, Rasio Profitabiltas, dan Rasio Leverage terhadap Financial Distress (Studi pada Perusahaan Tekstil dan Garmen yang Terdaftar di Bursa Efek Indonesia Tahun 2011-2015). E-Proceeding of Management, 4(1), 411-419. Retrieved From Https://Openlibrarypublications.Telkomuniversity.Ac.Id/Index.Php/Management/Article/View/ $4419 / 4149$

Almilia, L. S., \& Kristijadi. (2003). Analisis Rasio Keuangan untuk Memprediksi Kondisi Financial Distress Perusahaan Manufaktur yang Terdaftar di Bursa Efek Jakarta. Jaai, 7(2), 1-28. Https://Journal.Uii.Ac.Id/Jaai/Article/View/846

Andre, O., \& Taqwa, S. (2014). Pengaruh Profitabilitas, Likuiditas, dan Leverage dalam Memprediksi Financial Distress ( Studi Empiris pada Perusahaan Aneka Industri yang Terdaftar di Bei Tahun 2006-2010 ). Jurnal Wahana Riset Akuntansi, 2(1), 293-312.

Ardian, A. V., Andini, R., \& Raharjo, K. (2016). Pengaruh Rasio Likuiditas, Rasio Leverage, Rasio Aktifitas dan Rasio Profitabilitas terhadap Financial Distress. Jurnal.Unpand.Ac.Id, 3(3), 1-15.

Ayu, A., Handayani, S., \& Topowijono, T. (2017). Pengaruh Likuditas, Leverage, Profitabilitas, dan Ukuran Perusahaan terhadap Financial Distress Studi pada Perusahaan Manufaktur Sektor Industri Dasar dan Kimia yang Terdaftar Di Bursa Efek Indonesia Tahun 2012-2015). Jurnal Administrasi Bisnis S1 Universitas Brawijaya, 43(1), 138-147. 
Hasivatus Sariroh. Pengaruh Likuiditas, Leverage, Profitabilitas, dan Ukuran Perusahaan terhadap Financial Distress di Sektor Trade, Service, and Invesment

Bodroastuti, T. (2009). Pengaruh Struktur Corporate Governance terhadap Financial Distress. Jurnal Ilmu Ekonomi ASET, 11(2), 1-12.

Brigham, E. dan H. (2001). Manajemen Keuangan Buku 1 Edisi Kedelapan. Jakarta: Erlangga.

Carolina, V., \& Pratama, D. (2017). Analisis Rasio Keuangan untuk Memprediksi Kondisi Financial Distress ( Studi Empiris pada Perusahaan Manufaktur yang Terdaftar di Bursa Efek Indonesia Periode 2014-2015 ). Jurnal Akuntansi Maranatha, 9(2), 137-145.

Dewi, N. K. U. G., \& Dana, M. (2017). Variabel Penentu Financial Distress pada Perusahaan Manufaktur di Bursa Efek Indonesia. E-Jurnal Manajemen Unud, 6(11), 3-24.

Eloumi and Gueyie. (2001). Financial Ditress and Corporate Governance: An Empirical Analysis. Journal Corporate Governance, 1, 15-23.

Fahmi, I. (2011). Analisis Laporan Keuangan. Bandung: Alfabeta.

Gobenvy, O. (2014). Pengaruh Profitabilitas, Financial Leverage dan Ukuran Perusahaan Terhadap Financial Distress pada Perusahaan Manufaktur yang Terdaftar di Bursa Efek Indonesia Tahun 2009-2011. Jurnal Akuntansi, 2(1), 1-24.

Hidayat, M. A., \& Meiranto, W. (2014). Prediksi Financial Distress Perusahaan Manufaktur di Indonesia. Diponegoro Journal Of Accoumting, 3(3), 1-11.

Januarti, I. (2009). Analisis Pengaruh Faktor Perusahaan, Kualitas Auditor, Kepemilikan Perusahaan Terhadap Penerimaan Opini Audit Going Concern ( Perusahaan Manufaktur yang Terdaftar di Bursa Efek Indonesia ). Jurnal Universitas Diponegoro, 1(1), 1-26.

Julius, F. (2017). Pengaruh Finacial Leverage, Firm Growth, Laba dan Arus Kas terhadap Financial Distress (Studi Empiris pada Perusahaan Manufaktur yang Terdaftar di Bursa Efek Indonesia Tahun 2010-2014). Jom Fekon, 4(1), 14-15.

Kasmir. (2008). Analisis Laporan Keuangan. Jakarta: Kharisma Putra Utama Offset.

Kazemian, S., Shauri, N. A. A., Sanusi, Z. M., Kamaluddin, A., \& Shuhidan, S. M. (2017). Monitoring mechanisms and financial distress of public listed companies in Malaysia. Journal of International Studies, 10(1), 92-109. https://doi.org/10.14254/2071-8330.2017/10-1/6

Kholidah, A. N., Gumanti, T. A., \& Mufidah, A. (2016). Analisis Rasio Keuangan dalam Memprediksi Financial Distress pada Perusahaan Sektor Industri Dasar dan Kimia yang Terdafatar di Bei Tahun 2011-2015. Jurnal Bisnis dan Manajemen, 10(3), 279-291.

Lindawati. (2014). Pengaruh Rasio Leverage dan Rasio Likuiditas terhadap Kondisi Financial Distress (Studi Kasus pada Perusahaan Sub Sektor Transportasi yang Terdaftar di Bursa Efek Indonesia Periode 2007-2013). Jurnal Akuntansi, 10(5), 1-24.

Mas'ud, I., \& Srengga, R. M. (2015). Analisis Rasio Keuangan untuk Memprediksi Kondisi Financial Distress Perusahaan Manufaktur yang Terdaftar di Bursa Efek Indonesia. Jurnal Akuntansi Universitas Jember, 10(2), 139-154.Muflihah, I. Z. (2017). Analisis Financial Distress Perusahaan Manufaktur di Indonesia dengan Regresi Logistik. Majalah Ekonomi, Xxii(2), 254269.

Muflihah, I. Z. (2017). Analisis Financial Distress Perusahaan Manufaktur di Indonesia dengan Regresi Logistik. Majalah Ekonomi, Xxii(2), 254-269. 
Nanayakkara, K. G. M., \& Azeez, A. A. (2015). Predicting Corporate Financial Distress In Sri Lanka With Reference To Z-Score Model. Ijbsr, 5(3), 41-56. Https://Doi.Org/10.4038/Kjm.V3i1.7474

Ningsih, S. E. S. (2012). Analisis Corporate Governance dan Rasio Keuangan dalam Memprediksi Kesulitan Keuangan pada Perusahaan Manufaktur di BEI. Berkala Ilmiah Mahasiswa Akuntansi, 1(6), 105-110.

Nukmaningtyas, F., \& Worokinasih, S. (2018). Penggunaan Rasio Profitabilitas, Likuiditas, Leverage dan Arus Kas untuk Memprediksi Financial Distress (Studi pada Perusahaan Sektor Aneka Industri yang Terdaftar di Bursa Efek Indonesia Periode 2013 - 2016). Jurnal Administrasi Bisnis, 61(2), 136-143.Nurhidayah, \& Rizqiyah, F. (2017). Kinerja Keuangan Dalam Memprediksi Financial Distress. Jibeka, 11(1), 42-48. Retrieved from www.bi.go.id

Nurhidayah, \& Rizqiyah, F. (2017). Kinerja Keuangan dalam Memprediksi Financial Distress. Jibeka, 11(1), 42-48. https://jurnal.stie.asia.ac.id/index.php/jibeka/article/view/59

Patunrui, K. I. A., \& Yati, S. (2018). Analisis Penilaian Financial Distress Menggunakan Model Altman (Z-Score) pada Perusahaan Farmasi yang Terdaftar di Bursa Efek Indonesia Periode 2013-2015. Jurnal Akuntansi, Ekonomi Dan Manajemen Bisnis, 5(1), 55-71. https://doi.org/10.30871/jaemb.v5i1.275

Platt, H., \& Platt, M. B. (2002). Predicting Financial Distress. Journal of Financial Service Professionals, 5(6), 12-15.

Putri, N. W. K. A., \& Merkusiwati, N. K. L. A. (2014). Pengaruh Mekanisme Corporate Governance, Likuiditas, Leverage, dan Ukuran Perusahaan pada Financial Distress. E-Jurnal Akuntansi, 7(1), 93-106.

Rahayu, W. P., \& Sopian, D. (2017). Pengaruh Rasio Keuangan dan Ukuran Perusahaan terhadap Financial Distress (Studi Empiris pada Perusahaan Food and Beverage di Bursa Efek Indonesia). Competitive Jurnal Akuntansi dan Keuangan, 1(2), 1-13.

Ripais, M. (2014). Pengaruh Rasio Likuiditas, Rasio Leverage, Rasio Profitabilitas terhadap Kondisi Financial Distress Perusahaan Manufaktur yang Terdaftar di BEI Periode 2009-2013. Jurnal.Umrah, 9(3), 14-15 https://jurnal.umrah.ac.id/archives/4134.

Saleh, A., \& Sudiyatno, B. (2013). Pengaruh Rasio Keuangan untuk Memprediksi Probabilitas Kebangkrutan pada Perusahaan Manufaktur yang Terdaftar di Bursa Efek Indonesia. Dinamika Akuntansi, Keuangan dan Perbankan, 2(1), 82-91.

Santoso, I. S., Fala, Y. A. S. D., \& Khorin, A. N. N. (2017). Pengaruh Laba, Arus Kas dan Corporate Governance terhadap Financial Distress. Jurnal Al-Buhuts, 1(1), 1-22.

Sari, N. L. K. M., \& Putri, I. G. A. M. A. D. (2016). Kemampuan Profitabilitas Memoderasi Pengaruh Likuiditas dan Leverage terhadap Financial Distress. Juara Jurnal Riset Akutansi, 6(1), 34193448 .

Sudana, I. M. (2009). Manajemen Keuangan Teori dan Praktik. Surabaya: Pusat Penerbitan dan Percetakan (AUP).

Suprobo, M. D., Mardani, R. M., \& Wahono, B. (2017). Pengaruh Likuiditas Leverage dan Profitabilitas terhadap Financial Distress pada Perusahaan Trasnportasi yang Terdaftar Di Bursa Efek Indonesia (Bei) Tahun 2011-2015. E-Jurnal Riset Manajemen, 6(10), 77-97. http://riset.unisma.ac.id/index.php/jrm/article/view/573 
Hasivatus Sariroh. Pengaruh Likuiditas, Leverage, Profitabilitas, dan Ukuran Perusahaan terhadap Financial Distress di Sektor Trade, Service, and Invesment

Tandelilin, E. (2010). Portofolio dan Investasi Teori dan Aplikasi. Yogyakarta: Penerbit Kanisius.

Waqas, H., \& Md-Rus, R. (2018). Predicting financial distress: Importance of accounting and firmspecific market variables for Pakistan's listed firms. Cogent Economics and Finance, 6(1), 116. https://doi.org/10.1080/23322039.2018.1545739

Wardhani, R. (2007). Mekanisme Corporate Governance dalam Perusahaan yang Mengalami Permasalahan Keuangan. Jurnal Akuntansi dan Keuangan Indonesia, 4(1), 95-114. Https://Doi.Org/10.21002/Jaki.2007.05

Whitaker, R. (1999). The Early Stages of Financial Distress. Journal of Economics and Finance, 2(3), 123-133.

Wibowo, R. A. W., \& Raharja. (2014). To-Equity Ratio, dan Return On Equity terhadap Return Saham. Diponegoro Journal Of Accoumting, 3(3), 1-11.

Yustika, Y. (2015). Pengaruh Likuiditas, Leverage, Profitabilitas, Operating Capacity dan Biaya Agensi Manajerial terhadap Financial Distress (Studi Empiris pada Perusahaan Manufaktur yang Terdaftar di Bursa Efek Indonesia Tahun 2011-2013). Jom Fekon, 2(2), 1-15. 